\title{
Influence of Consistency and Composition of Growth Medium on Surface Physicochemical Properties of Streptomyces
}

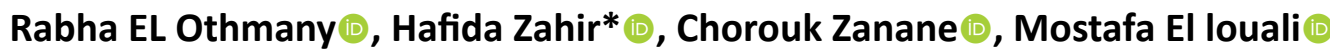 \\ and Hassan Latrache
}

Laboratory of Bioprocess and Biointerfaces, Faculty of Sciences and Technics, Sultan Moulay Slimane University, B.P. 523, 23000, Beni Mellal, Beni-Mellal 23000, Morocco.

\begin{abstract}
Streptomyces are known for their ability to produce various secondary metabolites used in biotechnology, human medicine and agriculture. Understanding of surface properties is very interesting in the control of interfacial phenomena. The objective of this study was to investigate the effect of consistency and composition of growth medium on the physicochemical properties of the surface of Streptomyces strains. To achieve this objective, Six Streptomyces strains belonging to bioprocess and bio-interfaces laboratory are cultivated in two media Bennett (rich) and GBA (minimum). Both media are tested in solid (agar) and liquid (broth) mode. The wettability $\theta w$, electron donor character ${ }^{\gamma}(-)$, electron acceptor character ${ }^{\gamma}(+)$ and Surface free energy $\Delta G_{i w i}$ are determined using contact angle measurements. On the two solid media Bennett and GBA, Streptomyces strains develop a hydrophobic surface $\left(96.9^{\circ}<\theta \mathrm{w}<167.9^{\circ}\right)$ with a weak electron donor character $\left(0.3 \mathrm{mJm}^{-2}<\left({ }^{\gamma}(-)\right)<12.14 \mathrm{mJm}^{-2}\right)$ and a strong electron acceptor character $\left(0.26 \mathrm{mJm}^{-2}<{ }^{\gamma}(+)<17.8 \mathrm{mJm}^{-2}\right)$ and a negative surface free energy $\left(\left(-11.8 \mathrm{mJm}^{-2}\right)<\Delta \mathrm{G}_{\text {iwi }}<\left(-110 \mathrm{mJm}^{-2}\right)\right)$. Whereas on both Bennett and GBA liquid media, the surfaces of Streptomyces strains are generally hydrophilic $\left(1.3^{\circ}<\theta \mathrm{w}<9.33^{\circ}\right)$ with a strong electron donor character $\left(13.76 \mathrm{mJm}^{-2}<\left({ }^{\gamma}(-)\right)<70.06 \mathrm{mJm}^{-2}\right)$ and a positive surface free energy. By changing the composition of the culture medium, only a slight change in the degree of hydrophobicity and surface free energy of Streptomyces is observed. Regarding the effect of medium composition on the surface properties of Streptomyces, the degree of wettability and the values of surface free energy are no longer the same when the composition of the medium changes. These results could be applied in further studies interested in interfacial phenomena and microbial adhesion in biotechnological fields.

Keywords: Surface physico-chemical properties, Growth medium, agar, liquid, Streptomyces, contact angle measurement
\end{abstract}

*Correspondence: hafidazahir@yahoo.com

(Received: January 11, 2021; accepted: June 25, 2021)

Citation: EL-Othman R, Zahir H, Zanane C, Ellouali M, Latrache H. Influence of Consistency and Composition of Growth Medium on Surface Physicochemical Properties of Streptomyces. J Pure App/ Microbiol. 2021;15(3):1705-1715. doi: 10.222207/JPAM.15.3.67

C The Author(s) 2021. Open Access. This article is distributed under the terms of the Creative Commons Attribution 4.0 International License which permits unrestricted use, sharing, distribution, and reproduction in any medium, provided you give appropriate credit to the original author(s) and the source, provide a link to the Creative Commons license, and indicate if changes were made. 


\section{INTRODUCTION}

Streptomyces is a bacterial group belonging to the phylum Actinobacteria. They contribute to the production of many useful molecules in biotechnology. Streptomyces are characterized by a complex and special development cycle $^{1,2}$. This complexity of their growth explains the limited number of studies on adhesion, surface tensions components in this important genus.

Currently, Streptomyces are used in several biotechnological processes ${ }^{1,3,4}$. However, deep studies on the surface properties and the influencing parameters are still limited ${ }^{5-7}$. The examination of the surface properties could be used for the control of the cell attachment processes in the reactors and subsequently the control of the stability ${ }^{8}$ and the metabolism of the Strain?.

Early investigations on the physicochemistry of the microbial surface have shown the relationships between hydrophobicity and acid-base character and the implication of these parameters in the interaction of microbes with supports ${ }^{10}$. Then, the extended theory DerjaguinLandau-Verwey-Overbeek XDLVO ${ }^{11}$ has allowed the determination of microbial surface tensions.

In very recent studies the surface properties have been used in the control and management of adhesion in different fields ${ }^{12-16}$. It has been shown for other bacteria such as E.coli ${ }^{17}$ and Lactobacillus ${ }^{18}$ that the culture conditions affect the properties of the bacterial surface. However, for Streptomyces few reports are available in this issue ${ }^{5,7}$. To our knowledge, No studies have been performed to test the effect of the composition and consistency of culture medium on the surface properties of Streptomyces.

The objective of this research is to analyze the surface properties of Streptomyces in order to extend the knowledge about this important genus of bacteria and to provide useful data for the control of adhesion/attachment in biotechnology. We tested the effect of consistency and composition of the culture medium on the hydrophobicity, electron donor/acceptor character and surface free energy of six Streptomyces strains.

\section{MATERIALS AND METHODS}

Bacterial strains, culture conditions and preparation of microbial suspension

Streptomyces strains are belonging to bioprocess and bio-interface laboratory, they are isolated from Moroccan saline soil and identified in a previous study ${ }^{19}$.

Streptomyces strains are cultivated in two Liquid mediums which were different in the composition were chosen in this study, liquid Bennett (Glucose $10 \mathrm{~g} /$; yeast extract $2 \mathrm{~g} / \mathrm{l}$; meat extract $1 \mathrm{~g} / \mathrm{l}$; peptone $2 \mathrm{~g} / \mathrm{l}, 1$ liter of distilled water) and liquid GBA (Glycerol $20 \mathrm{~g} / \mathrm{l}$; soluble starch $10 \mathrm{~g} / \mathrm{l} ; \mathrm{CaCO}_{3} 3 \mathrm{~g} / \mathrm{l}$; peptone $10 \mathrm{~g} / \mathrm{l}$; meat extract $5 \mathrm{~g} / \mathrm{l})$. Strains were grown 7 days at $28^{\circ} \mathrm{C}$ under shaking. Then, cells were harvested by centrifugation for $15 \mathrm{~min}$ at $84000 \times \mathrm{g}$, washed twice and suspended in potassium nitrate solution $\left(\mathrm{KNO}_{3}, 0,1 \mathrm{M}\right)$.

Two agar medium used for this study agar Bennett (Glucose $10 \mathrm{~g} / \mathrm{l}$; yeast extract $2 \mathrm{~g} / \mathrm{l}$; meat extract $1 \mathrm{~g} / \mathrm{l}$; peptone $2 \mathrm{~g} / \mathrm{l}, 1$ liter of distilled water and bacteriological agar 18g/l ). Agar GBA Glycerol $20 \mathrm{~g} / \mathrm{l}$; soluble starch $10 \mathrm{~g} / \mathrm{l} ; \mathrm{CaCO}_{3} 3 \mathrm{~g} / \mathrm{l}$; peptone $10 \mathrm{~g} / \mathrm{l}$; meat extract $5 \mathrm{~g} / \mathrm{l}$ and bacteriological agar $18 \mathrm{~g} / \mathrm{l}$ ). After 7 days at $28^{\circ} \mathrm{C}$, pieces of agar containing a bacterial layer has been cut for later contact angle measurements.

\section{Contact angle measurements and estimation of} bacterial surface tension components

Briefly, bacterial cells suspended in $\mathrm{KNO}_{3} 0.1 \mathrm{M}$ were filtered through nitrocellulose filter with $0.45 \mu \mathrm{m}$ pore size using a negative pressure. The filters were left during about $30 \mathrm{~min}$ to air dry at room temperature until contact angle measurements. Experiments were carried out in triplicate for each strain. Contact angle measurements were accomplished using a goniometer (GBX Instruments, France) by sessile drop method. A drop of $10 \mu$ of the liquid test (water, formamide or diiodomethane) was dispensed on the surface of the filter. Wettability was obtained directly by measuring the contact angle with water. The surface tension components are determined based on YoungDupre equation which is related to the surfaces tension components in equation (1)

Surface free energy $\left(\Delta G^{\text {iwi }}\right)$, Lifshitz-van der Waals components $\left(\gamma^{\mathrm{LW}}\right)$, electron donor 
character or Lewis base $\left(\gamma^{-}\right)$and acceptor character of electron or Lewis acid $\left.\left(\gamma^{+}\right)\right)$were estimated from the approach proposed by Van Oss ${ }^{20}$. In this approach the pure liquid $(\mathrm{L})$ contact angles $(\theta)$ can be expressed as:

$\cos \theta=-1+2 \frac{\sqrt{\gamma_{S}^{L W} \gamma_{L}^{L W}}+\sqrt{\gamma_{S}^{+} \gamma_{L}^{-}}+\sqrt{\gamma_{S}^{-} \gamma_{L}^{+}}}{\gamma_{L}}$

As (S) and (L) mean solid phase and liquid phase respectively. The Lewis acid-base component has been obtained by:

$$
\gamma^{A B}=2 \sqrt{ } \gamma-\gamma+
$$

Cell surface hydrophobicity also called surface free energy is an expression of the Lifshitzcan der Waals $\gamma^{\mathrm{LW}}$ and acid-base $\gamma^{\mathrm{AB}}$ surface tensions ${ }^{21}$, it is usually assessed by contact angles of water, formamide and diiodomethane (purity $\geq$ $99 \%)$. Energies characteristics of theses solvents is presented in Table $1^{22}$.

The degree of hydrophobicity also called surface free energy was calculated by measuring the contact angle based on the Van Oss approach ${ }^{24}$. According to this approach the degree of hydrophobicity for a given material (i) is expressed as the interaction energy between two entities of a material (i) when it is immersed in water (w). The latter has been evaluated through surface tensions by the following equation (3):

$$
\Delta \mathrm{G}_{\mathrm{iwi}}=-2 \gamma_{\mathrm{iw}}=-2\left[\begin{array}{c}
\left(\left(\gamma_{i}^{L W}\right)^{\frac{1}{2}}-\left(\gamma_{w}^{L W}\right)^{\frac{1}{2}}\right)^{2}+ \\
2\left(\left(\gamma_{i}^{+} \gamma_{i}^{-}\right)^{\frac{1}{2}}+\left(\gamma_{w}^{+} \gamma_{w}^{-}\right)^{\frac{1}{2}}-\left(\gamma_{i}^{+} \gamma_{w}^{-}\right)^{\frac{1}{2}}-\left(\gamma_{w}^{+} \gamma_{i}^{-}\right)^{\frac{1}{2}}\right)
\end{array}\right]
$$

Contact angle measurements report the aptitude of a liquid to extent on a surface depending on its wettability. The principle of this method is to measure the angle $\theta$ of the tangent with the studied surface of the profile of a drop with defined dimensions, of a probe liquid deposited on the substrate to be analyzed.

Using water as a drop application liquid lead to conclude about surface wettability also called qualitative hydrophobicity. The use of different references liquids lead to evaluate the total surface free energy and its components based on Young-Dupre equation - presented in earlier paragraph- and also the energy components characterizing the analyzed substrate thermodynamically.

Using the approach of Van Oss ${ }^{20,24}$, it is possible to evaluate the absolute degree of hydrophobicity of surfaces. Based on the XDLVO approach, $\Delta G_{i w i}$ (surface free energy) can be calculated. Therefore, surfaces with positive surface free energy $\left(\Delta G_{i w i}>0\right)$ are classified as hydrophilic and surface with negative surface free energy $\left(\Delta \mathrm{G}_{\mathrm{iwi}}<0\right)$ are considered as hydrophobic.

\section{Statistical analysis}

We used SPSS (IBM, version 20 for Windows) for statistical analyses and considered $\mathrm{p}<0.05$ as statistically significant.

\section{RESULTS}

Physicochemical properties of Streptomyces strains in liquid GBA, agar GBA, liquid Bennett and agar Bennett media Wettability

Cell wettability or qualitative hydrophobicity $(\theta w)$, According to Vogler a surface is called hydrophobic if $\left(\theta w<65^{\circ}\right)^{25}$ while it is hydrophilic when $\theta w<65^{\circ 25}$. Wettability of Streptomyces surfaces on solid and broth culture media is presented in the Fig. 2. GBA and Bennett are used in the present study. All Streptomyces grown on agar media are relatively hydrophobic

Table 1. Energy characteristics of solvents used for contact angle measurements $\mathrm{s}^{23}: \gamma^{\mathrm{Lw}}:$ Van der Waals component of surface free energy Solvents; $\gamma+$ : Electron acceptor component of free surface energy of solvents; $\gamma$ : Electron donor component of free surface energy of solvents:

\begin{tabular}{lccccc}
\hline Solvent & Formule & $\gamma^{\mathrm{Lw}}\left(\mathrm{mJ} / \mathrm{m}^{2}\right)$ & $\gamma^{\mathrm{ab}}\left(\mathrm{mJ} / \mathrm{m}^{2}\right)$ & $\gamma^{+}\left(\mathrm{mJ} / \mathrm{m}^{2}\right)$ & $\gamma\left(\mathrm{mJ} / \mathrm{m}^{2}\right)$ \\
\hline Water & $\mathrm{H}_{2} \mathrm{O}$ & 21,8 & 51,0 & 25,5 & 25,5 \\
Diiodomethane & $\mathrm{CH}_{2} \mathrm{I}_{2}$ & 50,8 & $\sim 0$ & $\sim 0$ & $\sim 0$ \\
Formamide & $\mathrm{CH}_{3} \mathrm{NO}$ & 39,0 & 19 & 2,3 & 39,6 \\
\hline
\end{tabular}


$\left(96.9^{\circ}<\theta w<167.9^{\circ}\right)$. Except Streptomyces griseorubens $A 23$ which was hydrophilic on agar GBA $\left(\theta w=17.3^{\circ}\right)$. However, on liquid mediums streptomyces strains showed a hydrophilic behavior $(1.3<\theta w<59.33)$. Our results showed a significant change in qualitative hydrophobicity between solid and liquid media. From GBA to Bennett media, cell surface properties exhibits slight changes. Wilcoxon text performed on the data significance 0.05 .

\section{Electron donor- Electron acceptor characters}

From figure 2 and figure 3 we observe that Streptomyces surface is highly electron donor $\left(13.76 \mathrm{~mJ} \mathrm{~m}^{-2} ; 70.06 \mathrm{~mJ} \mathrm{~m}^{-2}\right) /$ weakly electron acceptor $\left(0.43 \mathrm{~mJ} \mathrm{~m}^{2} ; 14.96 \mathrm{~mJ} \mathrm{~m}^{2}\right)$ when cultivated on liquid media. However, on solid media Streptomyces cell surfaces are considered as bipolar, acid components and base components are slightly similar. Electron donor values vary from $0.57 \mathrm{~mJ} \mathrm{~m}^{-2}$ to $13.75 \mathrm{~mJ} \mathrm{~m}^{-2}$ and electron acceptor vary from $0.04 \mathrm{~mJ} \mathrm{~m}^{-2}$ to $17.8 \mathrm{~mJ} \mathrm{~m}^{-2}$ (data presented in Fig. 2 and 3). Wilcoxon test confirm at 0.95 that the composition impact significantly the electron donor/ electron acceptor. Whereas, non-significant fluctuation was observed when the composition of growth medium was substituted.

\section{Surface free energy}

Surface free energy $\left(\Delta \mathrm{G}_{\mathrm{iwi}}\right)$ indicates the quantitative hydrophobicity. The surface is called hydrophobic if $\Delta \mathrm{G}_{\mathrm{iwi}}<0$ negative and hydrophilic

Table 2. Wettability of Six Streptomyces strains (in degree),grown in Bennett liquid, agar Bennett, GBA liquid, and agar GBA media

\begin{tabular}{|c|c|c|c|c|}
\hline & \multicolumn{4}{|c|}{ Wettability $\left(^{\circ}\right)$ of Streptomyces cell cultivated on GBA and Bennett medium } \\
\hline & $\begin{array}{l}\text { Ow agar } \\
\text { Bennett }\end{array}$ & $\begin{array}{l}\text { Ow liquid } \\
\text { Bennett }\end{array}$ & $\begin{array}{c}\theta w \text { agar } B A \\
\text { GBA }\end{array}$ & $\begin{array}{c}\text { Ow liquid } \\
\text { GBA }\end{array}$ \\
\hline Streptomyces griseorubens A3 & $134.54 \pm 6.824$ & $59.334 \pm 7.617$ & $167.9 \pm 9.753$ & $6.4 \pm 1.153$ \\
\hline Streptomyces bellus A7 & $148 \pm 2.86$ & $28.267 \pm 0.416$ & $117.1334 \pm 8.295$ & $1.3 \pm 0.45$ \\
\hline Streptomyces bellus A10 & $128 \pm 6.06$ & $15.334 \pm 5.48$ & $136.6 \pm 6.547$ & $3.33 \pm 1.154$ \\
\hline Streptomyces griseorubens A14 & $133.1 \pm 9.12$ & $23.434 \pm 5.11$ & $97.7 \pm 5.183$ & $11.433 \pm 0.28$ \\
\hline Streptomyces griseorubens A15 & $143.64 \pm 3.05$ & $28.234 \pm 5.346$ & $96.9 \pm 0.346$ & $8.03 \pm 0.75$ \\
\hline Streptomyces griseorubens A23 & $116.57 \pm 5.79$ & $14.234 \pm 4.186$ & $17.3 \pm 0.5$ & $3.0 \pm 2.64$ \\
\hline
\end{tabular}

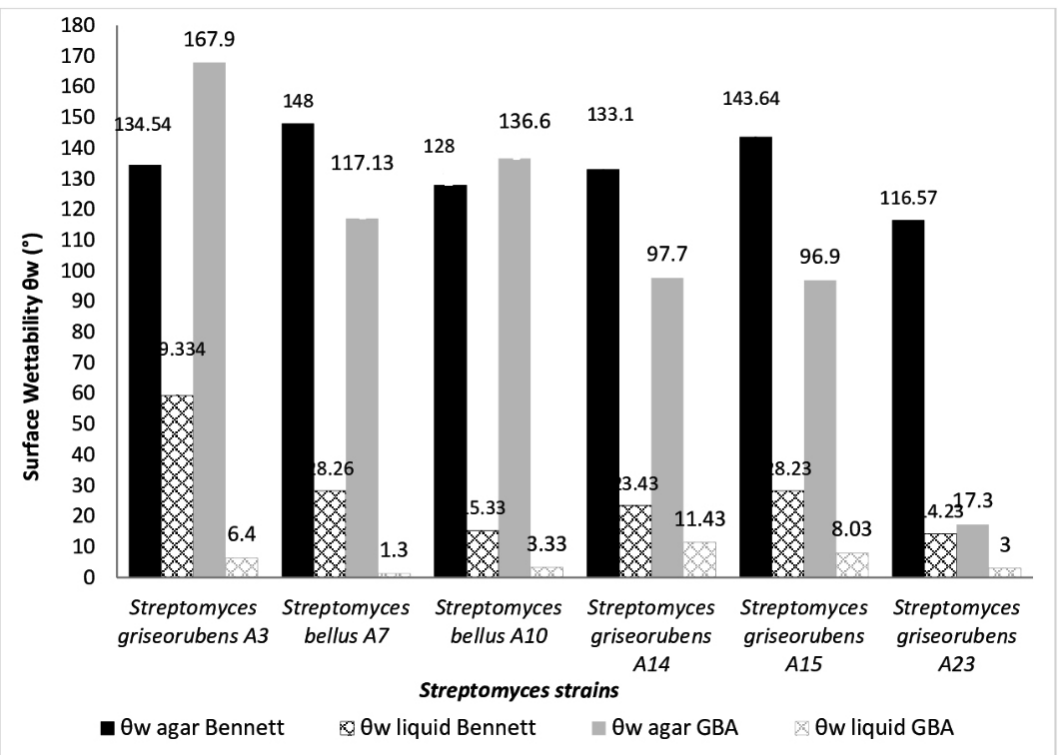

Fig. 1. Surface wettability $(\theta w)$ of Six Streptomyces strains cultivated on Bennett liquid, agar Bennett, GBA liquid and agar GBA media. 
when $\Delta \mathrm{G}_{\mathrm{iwi}}>0$ positive. Surface free energy of Streptomyces cells grown on Bennett and GBA media are mentioned in the Fig. 4. Bennett and GBA are used as agar and broth mode. Surface free energy of Streptomyces cultivated on agar Bennett and agar GBA are negative (from $\left(-11.86 \mathrm{mJm}^{2}\right.$ ) to $\left.\left(-110 \mathrm{mJm}-{ }^{2}\right)\right):\left(-11.86 \mathrm{mJm}-{ }^{2}<\Delta \mathrm{G}_{i w i}<-110 \mathrm{mJm}{ }^{2}\right)$. Streptomyces griseorubens A15 show a positive value of surface free energy $\left(+8.86 \mathrm{mJm}^{-2}\right)$.

On liquid media, surface free energy values are positives and included in this interval $\left(+12.9 \mathrm{mJm}^{-2}<\Delta \mathrm{G}_{\mathrm{iwi}}<+33.7 \mathrm{mJm}^{-2}\right)$.
The average values of the surface free energy obtained after growth on Agar Bennett $\left(-110 \mathrm{mJm}^{-2}<\Delta \mathrm{G}_{\text {iwi }}<-11.86 \mathrm{mJm}^{-2}\right)$, Agar GBA ($\left.67.36 \mathrm{mJm}^{-2}<\Delta \mathrm{G}_{\mathrm{iwi}}<+8.67 \mathrm{mJm}^{-2}\right)$, Liquid bennet $\left(-8 \mathrm{mJm}^{-2}<\Delta \mathrm{G}_{\mathrm{iwi}}<+33.7 \mathrm{mJm}^{-2}\right)$, and Liquid GBA $\left(+23 \mathrm{mJm}^{-2}<\Delta \mathrm{G}_{\mathrm{iwi}}<+34.9 \mathrm{mJm}^{-2}\right.$ ). (See Fig. 4)

\section{DISCUSSION}

\section{Streptomyces cells modify their wettability} behavior

The measurement of the surface wettability of Streptomyces strains has shown

Table 3. Electron donor of Six Streptomyces strains (in $\mathrm{mJ} \mathrm{m}^{-2}$ ), grown in Bennett liquid, agar Bennett, GBA liquid, and agar GBA media

\begin{tabular}{|c|c|c|c|c|}
\hline & \multicolumn{4}{|c|}{$\begin{array}{l}\text { Electron Donor }\left(\mathrm{mJ} \mathrm{m}-^{-2}\right) \text { of Streptomyces cell } \\
\text { cultivated on GBA and Bennett medium }\end{array}$} \\
\hline & $\begin{array}{l}{ }^{x}(-) \text { agar } \\
\text { Bennett } \\
(\mathrm{mJ} \mathrm{m-2})\end{array}$ & 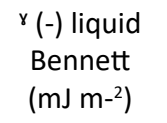 & $\begin{array}{c}{ }^{\gamma}(-) \text { agar } \\
\text { GBA } \\
\left(m J m^{-2}\right)\end{array}$ & $\begin{array}{c}{ }^{\gamma}(-) \text { liquid } \\
\text { GBA } \\
\left(\mathrm{mJ} \mathrm{m}^{-2}\right)\end{array}$ \\
\hline Streptomyces griseorubens A3 & $4.97 \pm 3.8$ & $13.76 \pm 7.60$ & $2.9 \pm 3.36$ & $56.43 \pm 0.46$ \\
\hline Streptomyces bellus A7 & $4.9 \pm 1.55$ & $46.3 \pm 7.16$ & $8.567 \pm 3.55$ & $54.867 \pm 0.15$ \\
\hline Streptomyces bellus A10 & $5.44 \pm 5.4$ & $70.06 \pm 7.96$ & $0.3 \pm 0.36$ & $52.93 \pm 0.152$ \\
\hline Streptomyces griseorubens A14 & $8.47 \pm 12.9$ & $53.06 \pm 3.81$ & $4.65 \pm 1.9$ & $55.267 \pm 2.884$ \\
\hline Streptomyces griseorubens A15 & $0.57 \pm 0.05$ & $53.3 \pm 5$ & $41.73 \pm 3.94$ & $56.4 \pm 0.3$ \\
\hline Streptomyces griseorubens A23 & $12.14 \pm 3.83$ & $55.2 \pm 1.47$ & $4.3 \pm 0.1$ & $54.9 \pm 0.264$ \\
\hline
\end{tabular}

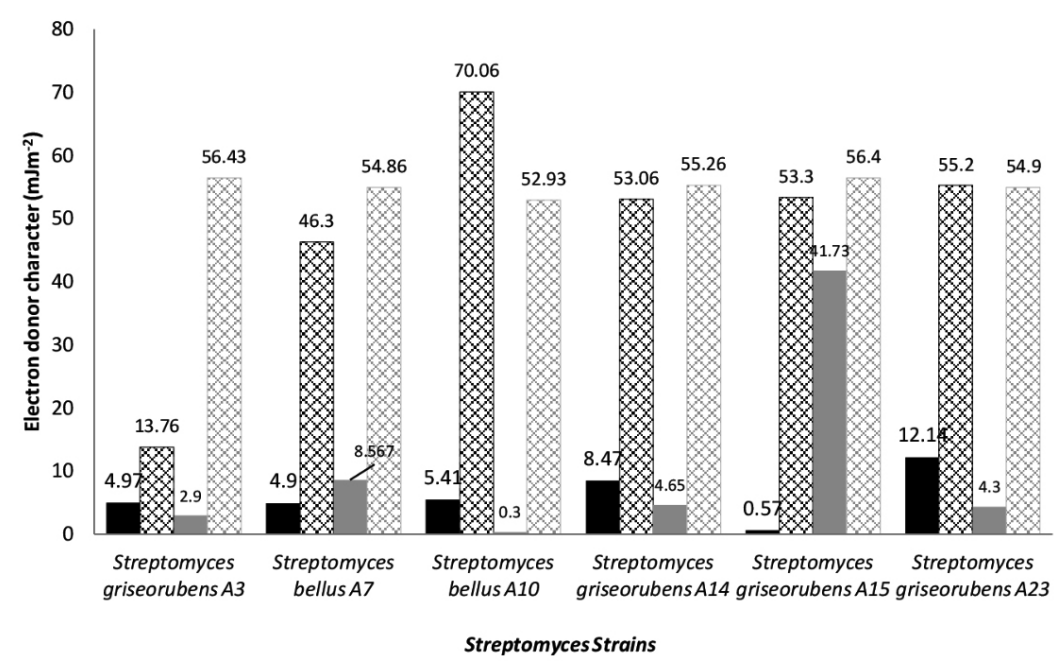

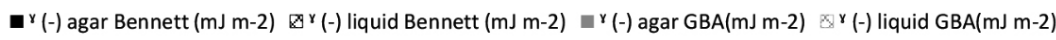

Fig. 2. Electron donor character $\left({ }^{\gamma}(-)\right.$ in $\left.\mathrm{mJm}-2\right)$ of Six Streptomyces strains cultivated on Bennett liquid, agar Bennett, GBA liquid and agar GBA media. 
that the surfaces of these strains are generally hydrophobic on solid medium (agar) and hydrophilic on liquid medium.

The development cycle of Streptomyces is characterized by its complexity. Spores undergo germination then vegetative hyphae develop into aerial hyphae. Aerial hyphae and spores are described in the work of Claessen and Elliot by specific proteins on the surface which allows the cells to rise from the liquid medium. We have characterized the surface after 7 days of incubation ${ }^{26,27}$.

Moreover, certain types of proteins expressed on the aerial hyphae called Chaplin. The latter are characterized by their amphipatic nature and anchored in the cell wall. These proteins undergo an assembly in such a way that the hydrophobic part is oriented towards the outside

Table 4. Electron acceptor of Six Streptomyces strains (in $\mathrm{mJ} \mathrm{m}^{-2}$ ),grown in Bennett liquid, agar Bennett, GBA liquid, and agar GBA media

\begin{tabular}{|c|c|c|c|c|}
\hline & \multicolumn{4}{|c|}{$\begin{array}{l}\text { Electron acceptor }(\mathrm{mJ} \mathrm{m-2}) \text { of Streptomyces cell } \\
\text { cultivated on GBA and Bennett medium }\end{array}$} \\
\hline & $\begin{array}{l}{ }^{\gamma}(+) \text { agar } \\
\text { Bennett } \\
\left(\mathrm{mJ} \mathrm{m}^{2}\right)\end{array}$ & $\begin{array}{c}{ }^{\gamma}(+) \text { liquid } \\
\text { Bennett } \\
\left(\mathrm{mJ} \mathrm{m}^{-2}\right)\end{array}$ & $\begin{array}{c}\mathrm{y}(+) \text { agar } \\
\text { GBA } \\
\left(\mathrm{mJ} \mathrm{m}^{2}\right)\end{array}$ & $\begin{array}{c}{ }^{\gamma}(+) \text { liquid } \\
\text { GBA } \\
(\mathrm{mJ} \mathrm{m-2})\end{array}$ \\
\hline Streptomyces griseorubens A3 & $1.74 \pm 0.08$ & $14.96 \pm 1.93$ & $3.13 \pm 0.73$ & $0.43 \pm 0.115$ \\
\hline Streptomyces bellus A7 & $5.2 \pm 0.98$ & $10.33 \pm 4.5$ & $1.33 \pm 0.98$ & $1.2 \pm 0.26$ \\
\hline Streptomyces bellus A10 & $6.97 \pm 1.68$ & $5.83 \pm 1.95$ & $0.26 \pm 0.25$ & $5.9 \pm 0.36$ \\
\hline Streptomyces griseorubens A14 & $16.4 \pm 8.05$ & $6.23 \pm 2.34$ & $0.55 \pm 0.07$ & $3.2 \pm 0.6$ \\
\hline Streptomyces griseorubens A15 & $0.04 \pm 0.05$ & $3 \pm 0.78$ & $8.6 \pm 7.44$ & $2.2 \pm 0.1$ \\
\hline Streptomyces griseorubens A23 & $1.77 \pm 1.15$ & $6.23 \pm 2.34$ & $17.8 \pm 0.1$ & $2.267 \pm 0.152$ \\
\hline
\end{tabular}

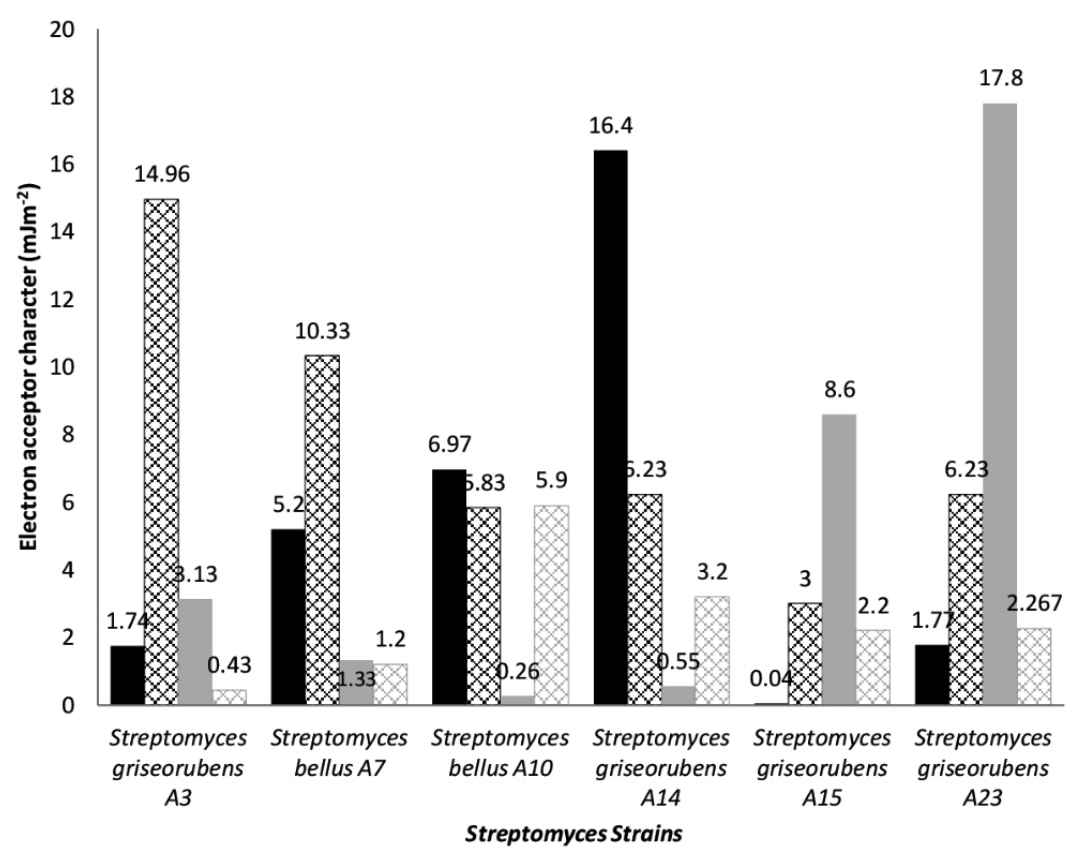

$$
\begin{array}{ll}
{ }^{\mathrm{x}}(+) \text { agar Bennett }(\mathrm{mJ} \mathrm{m}-2) & \triangle^{\mathrm{x}}(+) \text { liquid Bennett }(\mathrm{mJ} \mathrm{m}-2) \\
{ }^{\mathrm{x}}(+) \text { agar GBA }(\mathrm{mJ} \mathrm{m}-2) & \otimes^{\mathrm{x}}(+) \text { liquid }(\mathrm{mJ} \mathrm{m}-2) \mathrm{GBA}
\end{array}
$$

Fig. 3. Electron acceptor character $\left({ }^{\gamma}(+)\right.$ in $\left.\mathrm{mJm}-2\right)$ of Six Streptomyces strains cultivated on Bennett liquid, agar Bennett, GBA liquid and agar GBA media. 
of the cell thus conferring hydrophobicity to the aerial mycelium which contains them. Chaplins can be used to modify a variety of hydrophilic and hydrophobic surfaces in vitro thereby changing their nature. Assembly on glass leads to a protein coating that makes the surface hydrophobic ${ }^{28}$. On liquid medium the expression of surface proteins is neither as a solid medium where the cells undergo a transition from the vegetative phase to the aerial phase $^{29,30}$.

In addition, it was demonstrated that the availability of glucides and yeast extract in the fermentation medium impact the surface hydrophobicity of Lactobacillus acidophilus. Cell wall hydrophobicity, which is low for cultures grown in complete medium and in the absence of carbohydrates, becomes quite high for cultures grown in medium without peptones and medium without yeast extract ${ }^{18}$.

Kim et al. explained that Streptomyces growth in liquid media is characterized by the expression some specific molecules on the surface and the existence of DNA extracellular which make these pellets hydrophilic ${ }^{31}$.

Table 5. Surface free enegy of Six Streptomyces strains (in $\mathrm{mJ} \mathrm{m}^{-2}$ ), grown in Bennett liquid, agar Bennett, GBA liquid, and agar GBA media

\begin{tabular}{lcccc}
\hline & \multicolumn{4}{c}{$\begin{array}{c}\text { Surface free energy of Streptomyces cell } \\
\text { cultivated on GBA and Bennett medium }\end{array}$} \\
\cline { 2 - 5 } & $\begin{array}{c}\Delta \mathrm{G}_{\text {iwi }}\left(\mathrm{mJ} \mathrm{m-}{ }^{2}\right) \\
\text { agar Bennett }\end{array}$ & $\begin{array}{c}\Delta \mathrm{G}_{\text {iwi }}\left(\mathrm{mJ} \mathrm{m}^{2}\right) \\
\text { liquid Bennett }\end{array}$ & $\begin{array}{c}\Delta \mathrm{G}_{\text {iwi }}\left(\mathrm{mJ} \mathrm{m}-^{2}\right) \\
\text { agar GBA }\end{array}$ & $\begin{array}{c}\Delta \mathrm{G}_{\text {iwi }}\left(\mathrm{mJ} \mathrm{m}^{2}{ }^{2}\right) \\
\text { liquid GBA }\end{array}$ \\
\hline Streptomyces griseorubens A3 & $(-) 60.3 \pm 3.8$ & $(-) 8 \pm 3.40$ & $(-) 56.933 \pm 11.73$ & $34.9 \pm 0.6$ \\
Streptomyces bellus A7 & $(-) 56.17 \pm 1.11$ & $12.9 \pm 8.62$ & $(-) 47.833 \pm 2.74$ & $31.3 \pm 0.5$ \\
Streptomyces bellus A10 & $(-) 38.98 \pm 5.4$ & $33.7 \pm 11.08$ & $(-) 93.033 \pm 2.02$ & $23.0 \pm 0.7$ \\
Streptomyces griseorubens A14 & $(-) 11.86 \pm 12.9$ & $23.1 \pm 7.37$ & $(-) 67.367 \pm 9.58$ & $29.4 \pm 1.7$ \\
Streptomyces griseorubens A15 & $(-) 110 \pm 0.05$ & $29.8 \pm 5.05$ & $8.67 \pm 7.90$ & $32.5 \pm 0.5$ \\
Streptomyces griseorubens A23 & $(-) 41.61 \pm 5.02$ & $24.3 \pm 5.64$ & $(-) 15.567 \pm 7.13$ & $30.2 \pm 0.5$ \\
\hline
\end{tabular}

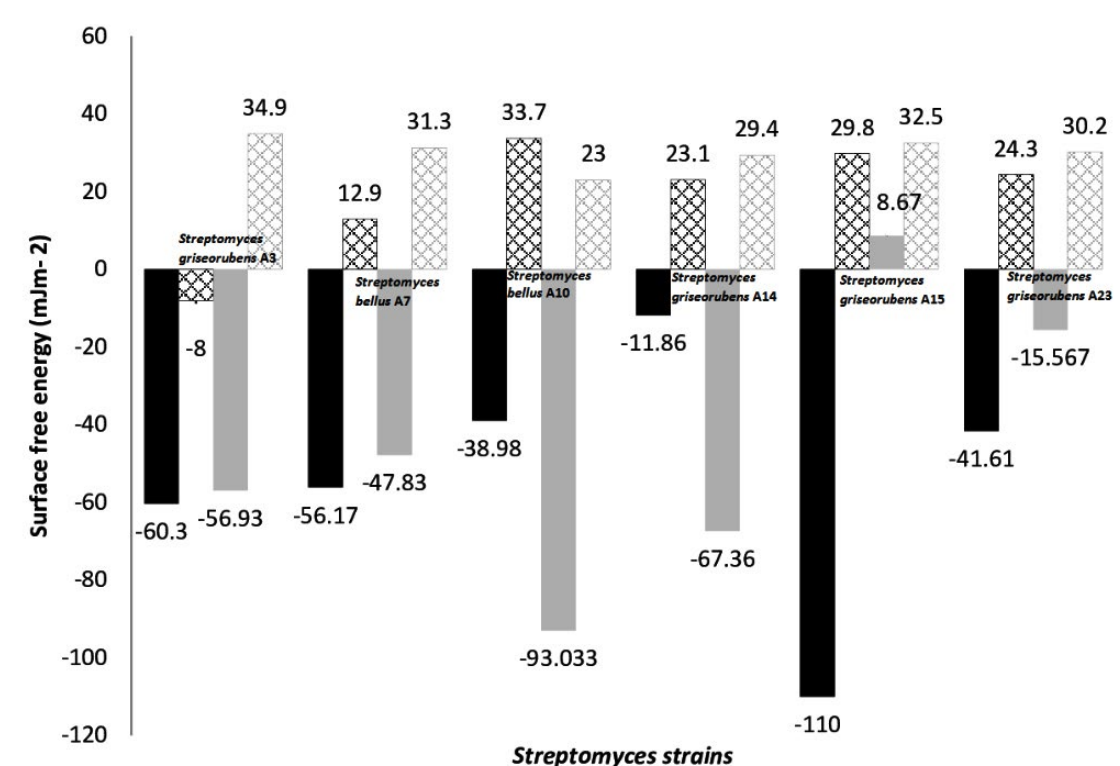

$$
\begin{array}{ll}
\text { - } \Delta \text { Giwi }(\mathrm{mJ} m-2) \text { agar Bennett } & \Delta \Delta \text { Giwi }(\mathrm{mJ} \mathrm{m}-2) \text { liquid Bennett } \\
\square \Delta \text { Giwi }(\mathrm{mJ} m-2) \text { agar GBA } & \square \Delta \text { Giwi }(\mathrm{mJ} \mathrm{m}-2) \text { liquid GBA }
\end{array}
$$

Fig. 4. The surface free energy (SFE) (in $\mathrm{mJm}^{-2}$ ) of Six Streptomyces strains cultivated on Bennett liquid, agar Bennett, GBA liquid and agar GBA media. 


\section{Electron donor / electron acceptor of Streptomyces surfaces}

The consistency of the culture medium affects significantly the electron donor/acceptor character, whereas the effect of the composition is not very pronounced. This change in the electron donor/acceptor character is probably due to the surface proteins. Various works concerning this issue are carried out on other bacteria. In fact, Briandet showed that cell surface charge, hydrophobicity and electron donor/electron acceptor character of Listeria monocytonenes ScottA strains change when glucose or lactic acid are added to growth medium ${ }^{23}$. In fact proteins structures are influenced by the amino-acid source available in the medium. In the same manner, other scientists showed the impact of growth conditions on physicochemical properties of bacteria like Enterococcus faecalis ${ }^{21}$, Lactobacilli strains $^{32}$, Enterocci strains ${ }^{33}$.

\section{Surface free energy (SFE) of Streptomyces} variations

Surface free energy (SEF) is from the important parameters required in interfacial phenomena. The obtained results from contact angle measurements and calculations of surface free energy of the surface of Streptomyces grown on broth Bennett, agar Bennett, liquid GBA and agar GBA showed a significant impact of the consistency and composition of surface free energy. These results lead to suggest that Streptomyces may use their advanced quorum sensing in detecting the environmental conditions. In fact, Jones et al. have highlighted that Streptomyces could exist as an exploratory growth. This bacterial group could detect organic volatil compounds coming from fungi and changes the morphology and the cells organization ${ }^{34}$.

Many interesting studies are carried on other bacteria in order to understand the factors affecting the Physico-chemistry of the bacterial surface. Latrache et al. demonstrated that Surface free energy and other surface tensions of Escherichia coli are not equivalent in solid LB medium as in liquid LB medium ${ }^{17}$. Also the environmental conditions such as $\mathrm{pH}$, ionic strength or presence of antimicrobial substances ${ }^{35}$ affect surface physicochemical properties. The surface tensions of Staphylococcus aureus and Escherichia coli are influenced by $\mathrm{pH}$ and ionic strength, their influence seemed to be significant on experimental adhesion assessed by scanning electron microscopy ${ }^{36}$. A deep analysis of the molecules of cell wall leads to explain the relationship between chemical composition of the cell wall and the electron donor/electron acceptor. Phosphate groups have a key role in evaluating the property of the electron donor (base). Amine groups decrease electron acceptor property (acid) ${ }^{37}$. Further Electron donor character electron acceptor character of bacterial surface are related to its composition on functional groups ${ }^{38}$. Contact angle measurements, xylene adsorption and cell partition in a polyethylene glycol/dextran (PEG/DEX) biphasic system are used to determine cell surface hydrophobicity of Escherichia coli. Chemical composition of bacterial surface obtained by XPS lead to determine $\mathrm{C} / \mathrm{O}$ and $\mathrm{C} / \mathrm{N}$ ratios also it can provide molecular content of the bacterial surface. A correlation obtained between these two parameters lead to conclude physicochemical properties from chemical analysis of cell surface ${ }^{39}$.

The conclusions and rules established derived from other bacteria could not be valuable for Streptomyces, because they have specific amino-acids in their cell wall ${ }^{40,41}$. However, Del sol reported that characterization of cell surface of Streptomyces using atomic force microscopy (AFM) indicated that vegetative hyphae are hydrophilic while aerial hyphae are hydrophobic. Vegetative hyphae have a relatively smooth surface and are attached to an inert silica surface by means of a secreted extracellular matrix. Aerial hyphae, which appear in aerial growth are poorly decorated with fibers ${ }^{42}$. In addition, analysis of extracted and identified extracellular proteins from vegetative and aerial hyphae showed different expression of proteome ${ }^{43}$.

From analysis of the cited literature above, The difference in surface free energy could be explained by the variation of the expression of proteins in each medium, since it is known that the culture medium in which bacterial survive plays a key role in cellular metabolism, as well as in the control of gene expression. Streptomyces wall depends on the composition of the medium and the availability of nutrients. 


\section{CONCLUSION}

Physicochemical properties of cell surface Streptomyces changes significantly depending on the consistency and composition of culture medium on which Streptomyces were grown. In fact, on both agar media the surfaces of Streptomyces were qualitatively and quantitatively hydrophobic, weak electron acceptor, weak electron donor (bipolar surface). However, on the two liquid mediums, the surfaces showed a qualitatively and quantitatively hydrophilic character, high electron donor character, weak electron acceptor character (monopolar surface). In addition, the levels of the qualitative hydrophobicity, the electron donor / electron acceptor characters and the quantitative hydrophobicity (surface free energy) differ according to the composition of growth medium. Thus, the characterization of surfaces properties of Streptomyces could be a key factor in the control of interfacial phenomenon.

\section{ACKNOWLEDGMENTS}

None.

\section{CONFLICT OF INTEREST}

The authors declare that there is no conflict of interest.

\section{AUTHORS' CONTRIBUTION}

$\mathrm{LH}, \mathrm{HZ}, \mathrm{ME}$ conceived and designed the experiments; REO and $C Z$ performed the experiments and analyzed the data; REO and $\mathrm{HZ}$ wrote the paper. All authors read and approved the manuscript.

\section{FUNDING}

None.

\section{DATA AVAILABILITY}

All datasets generated or analyzed during this study are included in the manuscript.

\section{ETHICS STATEMENT}

This article does not contain any studies with human participants or animals performed by any of the authors.

\section{REFERENCES}

1. Hopwood DA. Streptomyces in nature and medicine. Oxford University Press, New York, NY. 2007.

2. de Lima Procópio RE, da Silva IR, Martins MK, de Azevedo JL, de Araújo JM. Antibiotics produced by Streptomyces. Brazilian J Infect Dis. 2012;16(5):466471. doi:10.1016/j.bjid.2012.08.014

3. $\mathrm{Xu} \mathrm{D}$, Yao $H, \mathrm{Xu} \mathrm{Z}$, et al. Production of $\varepsilon$-polylysine by Streptomyces albulus PD-1 via solid-state fermentation. Bioresour Technol. 2017;223:149-156. doi:10.1016/j.biortech.2016.10.032

4. Pandey A, Soccol CR, Mitchell D. New developments in solid state fermentation: I-bioprocesses and products. Process Biochem. 2000;35(10):1153-1169. doi:10.1016/S0032-9592(00)00152-7

5. Maataoui H, Barkai H, Sadiki M, Haggoud A, Ibnsouda Koraichi S, Elabed S. Physicochemical characterization of actinomycetes isolated from decayed cedar wood: contact angle measurement. J Adhes Sci Technol. 2014;28(20):2046-2053. doi:10.1080/01694243.201 4.943341

6. El Othmany R, Zahir H, Ellouali M, Latrache H. Current Understanding on Adhesion and Biofilm Development in Actinobacteria. Int J Microbiol. 2021;2021:6637438. doi:10.1155/2021/6637438

7. Zahir H, Hamadi F, Mallouki B, Imziln B, Latrache $\mathrm{H}$. Effect of salinity on the adhesive power actinomycetes in soil. J. Mater. Environ. Sci, 2016;7(9):3327-3333.

8. Winn $M$, Casey $E$, Habimana $O$, Murphy CD. Characteristics of Streptomyces griseus biofilms in continuous flow tubular reactors. FEMS Microbiol Lett. 2014;352(2):157-164. doi:10.1111/1574-6968.12378

9. Petráčková $D$, Buriánková $K$, Tesařová $E$, et al. Surface hydrophobicity and roughness influences the morphology and biochemistry of streptomycetes during attached growth and differentiation. FEMS Microbiol Lett. 2013;342(2):147-156. doi:10.1111/15746968.12129

10. Van Der Mei HC, Bos R, Busscher HJ. A reference guide to microbial cell surface hydrophobicity based on contact angles. Colloids Surfaces $B$ Biointerfaces. 1998;11(4):213-221. doi:10.1016/ S0927-7765(98)00037-X

11. Van Oss CJ. Long-range and short-range mechanisms of hydrophobic attraction and hydrophilic repulsion in specific and aspecific interactions. J Mol Recognit. 2003;16(4):177-190. doi:10.1002/jmr.618

12. Liu Y, Zhao Q. Influence of surface energy of modified surfaces on bacterial adhesion. Biophys Chem. 2005;117(1):39-45. doi:10.1016/j.bpc.2005.04.015

13. Hori K, Matsumoto S. Bacterial adhesion : From mechanism to control. 2010;48:424-434. doi:10.1016/j. bej.2009.11.014

14. Hakim T, Lekchiri S, Amine Afilal M El, Ellouali M, Zahir $\mathrm{H}$, Latrache H. Modifying Supports Surfaces by Dairy Wastewater Conditioning Film and Relationship with Initial Bacterial Adhesion. Biosci Biotechnol Res Asia. 2020;17(03):525-533. doi:10.13005/bbra/2856

15. Koubali $H$, Latrache $H$, Zahir $H$, El Louali $M$. Kinetics of Adhesion Staphylococcus aureus on Glass in the 
Presence of Sodium Lauryl Sulfate. I Surfactants Deterg. 2021;24(3):483-490. doi:10.1002/jsde.12484

16. Azelmad K, Hamadi F, Mimouni R, El boulani A, Amzil $\mathrm{K}$, Latrache $\mathrm{H}$. Physicochemical characterization of Pseudomonas aeruginosa isolated from catering substratum surface and investigation of their theoretical adhesion. Surfaces and Interfaces. 2018;12:26-30. doi:10.1016/j.surfin.2018.04.004

17. Latrache H, Mozes N, Pelletier C, Bourlioux P. Chemical and physicochemical properties of Escherichia coli: variations among three strains and influence of culture conditions. Colloids Surfaces B Biointerfaces. 1994;2(13):47-56. doi:10.1016/0927-7765(94)80017-0

18. Zammaretti PS, Dillmann ML, D'Amico N, Affolter $M$, Ubbink J. Influence of Fermentation Medium Composition on Physicochemical Surface Properties of Lactobacillus acidophilust. Appl Environ Microbiol. 2005;71(12):8165-8173. doi: 10.1128/ AEM.71.12.8165-8173.2005

19. Zanane $\mathrm{C}$, Latrache $\mathrm{H}$, Elfazazi $\mathrm{K}$, Zahir H, Ellouali M. Isolation of actinomycetes from different soils of Beni Amir Morocco. J Mater Environ Sci. 2018;9(10):29943000. http://www.jmaterenvironsci.com.

20. Van Oss' CJ, Chaudhury MK, Good RJ. Interfacial Lifshitz-van Der Waals and Polar Interactions in Macroscopic Systems. Chem. Rev, 1988;88(6): 927-941. doi: 10.1021/cr00088a006

21. Gallardo-Moreno AM, González-Martín ML, Bruque $J M$, Pérez-Giraldo C. Changes on the physicochemical surface properties and adhesion behaviour of Enterococcus faecalis by the addition of serum or urine to the growth medium. Phys Chem Chem Phys. 2004;6(7):1512-1517. doi:10.1039/b314609j

22. Busscher HJ, Weerkamp AH, Van Der Mei HC, Pelt AWJ, Jong HP, Arends J. Measurement of the surface free energy of bacterial cell surfaces and its relevance for adhesion. Appl Environ Microbiol. 1984;48(5):980-983.

23. Briandet R, Meylheuc T, Maher C, Bellon-Fontaine MN. Listeria monocytogenes Scott A: cell surface charge, hydrophobicity, and electron donor and acceptor characteristics under different environmental growth conditions. Appl Environ Microbiol. 1999;65(12):53285333.

24. van Oss CJ. Acid-base interfacial interactions in aqueous media. Colloids Surfaces A Physicochem Eng Asp. 1993;78:1-49. doi:10.1016/0927-7757(93)803082

25. Vogler EA. Structure and reactivity of water at biomaterial surfaces. Adv Colloid Interface Sci. 1998;74(1-3):69-117. doi:10.1016/S00018686(97)00040-7

26. Elliot MA, Karoonuthaisiri N, Huang J, et al. The chaplins : a family of hydrophobic cell-surface proteins involved in aerial mycelium formation in Streptomyces coelicolor. Genes Dev, 2003:1727-1740. doi:10.1101/ gad.264403.Filamentous

27. Claessen D, Rink R, De Jong W, et al. A novel class of secreted hydrophobic proteins is involved in aerial hyphae formation in Streptomyces coelicolor by forming amyloid-like fibrils. Genes Dev. 2003;17(14):1714-1726. doi:10.1101/gad.264303

28. Ekkers DM, Claessen D, Galli F, Stamhuis EJ. Surface modification using interfacial assembly of the Streptomyces chaplin proteins. Applied Microbiology and Biotechnology,2014;98: 4491-4501.doi: 10.1007/ s00253-013-5463-z.

29. Manteca A, Alvarez R, Salazar N, Yagu P. Mycelium Differentiation and Antibiotic Production in Submerged Cultures of Streptomyces coelicolor. Appl Environ Microbiol, 2008;74(12):3877-3886. doi:10.1128/ AEM.02715-07

30. Yagüe P, López-García MT, Rioseras B, Sánchez J, Manteca A. Pre-sporulation stages of Streptomyces differentiation: state-of-the-art and future perspectives. FEMS Microbiol Lett. 2013;342(2):7988. doi:10.1111/1574-6968.12128

31. Kim Y-M, Kim J. Formation and dispersion of mycelial pellets of Streptomyces coelicolor A3(2). J Microbiol. 2004;42(1):64-67.

32. Kankaanpa $\mathrm{P}$, Yang B, Kallio H, Isolauri E, Salminen S. Effects of Polyunsaturated Fatty Acids in Growth Medium on Lipid Composition and on Physicochemical Surface Properties of Lactobacilli. Appl Environ Microbiol, 2004;70(1):129-136. doi:10.1128/ AEM.70.1.129

33. Gallardo-Moreno AM, González-Martín ML, Bruque JM, Pérez-Giraldo C, Sánchez-Silos R, Gómez-García AC. Influence of the growth medium, suspending liquid and measurement temperature on the physicochemical surface properties of two enterococci strains. J Adhes Sci Technol. 2003;17(14):1877-1887. doi:10.1163/156856103770572034

34. Jones SE, Ho L, Rees CA, Hill JE, Nodwell JR, Elliot MA. Streptomyces exploration is triggered by fungal interactions and volatile signals. Elife. 2017;6:e21738. doi:10.7554/eLife. 21738

35. Latrache H, Bourlioux P, Karroua M, Zahir H, Hakkou A. Effects of Subinhibitory Concentrations of Nitroxoline on the Surface Properties of Escherichia coli. Folia Microbiolgica. 2000;45(6):485-490.

36. Hamadi F, Latrache H, Ghmari AEL, Louali MEL. Effect of $\mathrm{pH}$ and ionic strength on hydrophobicity and electron donor and acceptor characteristics of Escherichia coli and Staphylococcus aureus. Ann Microbiol. 2004;54(2):213-225.

37. Hamadi F, Latrache $\mathrm{H}$, Elghmari A, Zahir H, Mabrrouki M, Elbouadili AE. Determination of Escherichia coli Negative Charge Concentration From XPS Data and Its Variation with pH. J Surf Anal. 2005;12(3). https:// www.researchgate.net/publication/262728593. Accessed February 14, 2020.

38. Hamadi F, Latrache $\mathrm{H}$, Zahir H, Elghmari A, Timinouni $M$, Ellouali $M$. The relation between Escherichia coli surface functional groups' composition and their physicochemical properties. Brazilian J Microbiol. 2008;39(1):10-15. doi:10.1590/S151783822008000100003.

39. Latrache H, El GA, Karroua M, et al. Relations between hydrophobicity tested by three methods and surface chemical composition of Escherichia coli. New Microbiol. 2002;25(1):75-82. http://www.ncbi.nlm. nih.gov/pubmed/11837394. Accessed August 3, 2019.

40. Shashkov AS, Ostash BE, Fedorenko VA, et al. Novel teichulosonic acid from cell wall of Streptomyces 
coelicolor M145. Carbohydr Res. 2012;359:70-75. doi:10.1016/J.CARRES.2012.05.018

41. Petit J-F, Munoz E, Ghuysen J-M. Peptide Cross-Links in Bacterial Cell Wall Peptidoglycans Studied with Specific Endopeptidases from Streptomyces albus G. Biochemistry. 1996;5(8):2764-2776. doi:10.1021/ BI00872A037

42. Del Sol R, Armstrong I, Wright C, Dyson P. Characterization of changes to the cell surface during the life cycle of Streptomyces coelicolor. Atomic force microscopy of living cells. J Bacteriol. 2007;189(6):2219-2225. doi:10.1128/JB.01470-06

43. Bibb MJ, Domonkos Á, Chandra G, Buttner MJ. Expression of the chaplin and rodlin hydrophobic sheath proteins in Streptomyces venezuelae is controlled by s BldN and a cognate anti-sigma factor, RsbN. Mol Microbiol. 2012;84:1033-1049. doi:10.1111/j.1365-2958.2012.08070.x 